\title{
NEEDS ASSESSMENT OF CHILDREN WORKING IN THE STREETS OF KABUL
}

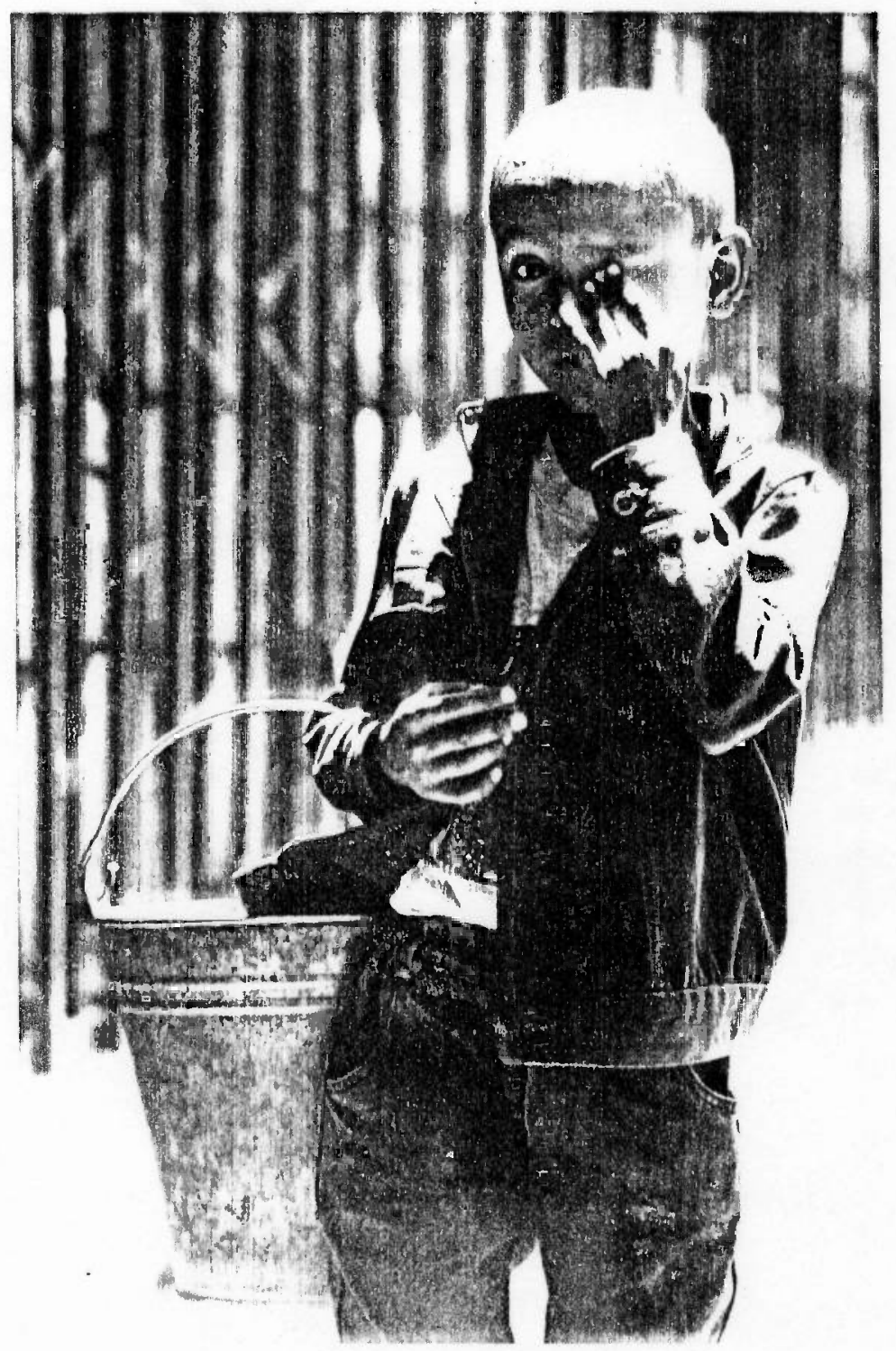

This Survey was funded by UNII(CR and TI)H

The Report was Prepared by TIDH

June 30,1996 


\title{
ACKNOWLEDGEMENTS
}

This Needs Assessment of Children Warking in the Streets in Kabul (Afghanistan) was the result of collaboration between Terre des hommes (Kabul), UNHCR (Kabul), the ACBAR Survey Unit (Peshawar, Pakistan), the staff of the Aschiana Centre (Kabul), and the many children and families who participated in the survey.

The survey was jointly funded by UNHCR and Terre des hommes (Tdh), and implemented by Tdh in Kabul. The Tdh Delegate, Ms. Cindy Dubble, designed the Needs Assessment questionnaire, prepared the survey methodology, and organised the field survey. The ACBAR Survey Unit in Peshawar completed the data entry and analysis. Mr. Abdul Hakim Murad, Survey Unit Manager, helped in the design of the questionnaire, and gave invaluable advice throughout the survey work. The final report was prepared jointly by the Tidh Delegate and the ACBAR data analyst (Mr. Hamidullah Azizi).

Special thanks must be given to the 20 surveyors, who worked tirelessly to correctly identify and interview the children and their families. Many days, they worked through rain, rockets, and the onset of the summer heat to complete the survey on time.

Special appreciation must also be given to Engineer Yousuf (Director of the Aschiana Programme) and Mr. Khalilullah H., Tdh Administrator, who organised the logistics, implemented the field survey, monitored the surveyors, and checked the survey questionnaires.

Finally, I would like to thank all the children and their families who participated in the Needs Assessment Survey for their time and cooperation. We hope that this survey will highlight the needs of the thousands of children who work in the streets of Kabul, and pay tribute to their courage to carry on.

\author{
Cindy Dubble \\ Delegate, Terre des hommes \\ Kabul, Afghanistan
}




\section{FORWARD --- NOORYA}

Noarya is an 8-year-old, Afghan girl. who spends her days scavenging firewood and paper from the streets of Kabul. She has been attending the Aschiama Centre for children working in the otreets, and related the stary of her life like this::

My father was a driver in Kabul. During the fighting, he was killed. My mother and my three sisters (one was only two days old when my father died) and I decided to go to our grandnother's house in Parwan province. When my grandmother died, we had to return to Kabul.

Now we are living with our aunt's family in a rented house. Our aunt lets us share her basement, which has a very damp floor. Because of the dampness, we have to take out the floor covering to be dried in the sun every day. Sometimes, my aunt's mother-in-law tells my aunt to throw us out so that she can bring her relatives to the house.

My mother earns money by washing other people's clothes. I have an uncle who will not help us. One day during Eid holidays, we went to our uncle's house and noticed that all our cousins were wearing new clothes. We weren't wearing new clothes as we cannot afford them. My uncle told iny mother that if my father were alive, he would have new clothes made for us. That made the whole family cry so much.

Several times afterwards when we went to my uncle's house, his wile treated us very badly and made us leave her house. She said that our uncle didn't have enough money for his own children, and could not feed more hungry mouths.

My work in the streets is to collect firewood and paper. I start at 7:00 in the morning, and after collecting some firewood, I go to Aschiana. After spending some time in Aschiana and eating lunch, I leave again to collect more firewood and take it home.

One of my saddest memories is that one day while I was collecting firewood and waste paper from a dump in Cliarahi Ilaji Yaqub, a rocket landed there. As soon as I heard the terrible sound of a rocket hitting the street, I went close to a wall. A passerby asked me what I was doing there and if I had a house to go to. I was so frightened and shocked that I ran from the wall and hid behind my sack of firewood, thinking that it would protect me from rocket shrapnel. After a while, I saw bodies lying around, some wounded and some killed. I didn't know what to do, and wlien I finally went home, I could not talk for a while.

Our biggest daily problem is that whenever we go to an area in scarch of firewood and paper, the other children of the area tease us, snatch away' our sacks and empty them, which is very frustrating. So I have to start all over again. This takes up alot of time, and I usually miss my classes at $\Lambda$ schiana. I want to study and learn more in the future, that is why I try my best to go to A schiana regularly.

When I go home in the evening, I help my mother with housework. Then I go to our neighbour's house to help the woman who was wounded in the rocket attack and is handicapped. When it is dark, we go to bed, and hope there will not be any rockets in the night. 
TABLE OF CONTENTS

Page Number

ACKNOWLEDGEMENTS

IOORWARD -- Noorya

if

ii

INTRODUCTION

OBJECTIVES 2

SURVEY METHODOLOGY

RESULTS OF THE NEEDS ASSESSMENT SURVEY

1. Prevalence of Children Working in the Streets in Kabul 5

2. Breakdown of 2,000 Children Surveyed by Sex 5

3. Location of the 2,000 Children Surveyed 6

4. Ages of the Children Surveyed 7

5. Ethnicity of Children Surveyed 8

6. Education of Children Surveyed 8

7. Length of 'Time the Children Have Worked in the Street 9

8. 'Working Hours of the Children 10

9. What Work do the Children Do? 11

10. How Much do the Children Earn? $12 \& 13$

11. Problems of Children Working in the Streets 12

12. Health Problems of the Children Surveyed 14

13. Where do the Children Live? "14

14. Children's Family Background 15

$\begin{array}{ll}\text { 15. Size of Families } & 16\end{array}$

16. Living Conditions of the Families 17

$\begin{array}{ll}\text { 17. Employment of Parents } & 17\end{array}$

$\begin{array}{ll}\text { 18. Income of the Families } & 17\end{array}$

19. Families' Perceptions of Why Their Children are 18 Working in the Streets

20. Families Perceptions of $\Lambda$ ssistance Needed 19

$\begin{array}{ll}\text { SUMMARY and CONCLUSIONS } & 20\end{array}$

Appendix A: List of Districts Surveyed

Appendix B: Survey Questionnaire 


\section{INTRODUCTION}

Noorya is only one of thousands of children who spend their daily lives working in the streets of Kabul. In every district of Kabul, children can be seen scavenging for firewood and paper, collecting scrap metal, cleaning cars, polishing shoes, selling food and water, and begging. Thousands more work as apprentices or assistants in shops, factories and garages, earning slave wages for long hours of grueling work. Some children cross the front-line and travel many kilometres to spend the day working in Kabul. Others risk their lives and limbs as they search for firewood and scrap metal in neighbourhoods full of landmines. For such children, every day is a fight for survival for themselves and their families.

These children are Kabul's legacy from 17 years of war. During the 10 years of fighting against the Russians, much of Afghanistan's countryside was destroyed, forcing thousands of displaced Afghans to seek shelter in Kabul. The swelling population and limited supplies resulted in economic hardship for the residents of Kabul. $\Lambda$ s thousands of men disappeared and died, women and children were left to fend for themselves, often having no alternative but to beg.

With the departure of the Russians, fighting in and around Kabul intensified as rival Mujahedeen groups fought for power and control of Kabul. Now, after 7 years of factional fighting, more than $70 \%$ of Kabul has been reduced to rubble, with thousands of people killed and maimed.

Kabul remains a city under siege, as the struggle for power continues between Rabbani's government and the Talibans. With rampant inflation and soaring prices, it is a desperate existence for most of Kabul's residents. The average salary of a government employee or doctor is only 200,000 Afghanis per month (approximately $\$ 13$ at current exchange rates). This can barely begin to cover the costs of feeding a family -- aid organisations in Kabul estimate the cost of basic living for a family of 6 to be Afs $1,575,000$ per month.

Against this backdrop, widespread use of child labour has developed, as economic necessity forces many families to send their children onto the streets. Some children have become successful entrepreneurs, but many are only able to earn a few thousand Afghanis for many long hours of work. They face the cold of winter, rockets, landmines. harassment by security forces, hunger and disease. An entire generation of children is being deprived of education and a secure childhood ...... the strect is their training ground for survival in a city at war.

Many local NGOs and international agencies have been concerned about the growing number of children in Kabul who spend their days in the streets. This Needs Assessment of Children Working in the Streets in Kabul is an attempt to collect baseline information about the thousands of children working in Kabul -- the first step in responding to their needs. 


\section{OBJECTIVES}

Specific Objectives of the Needs Assessment of Children Working in the Streets in Kabul were:

- To ascertain the prevalence of children working in the streets.

- To obtain data regarding the children's sex, ages, and living conditions.

- To obtain baseline information about the children's working patterns.

- To identify specific needs of children working in the streets.

- To gather information about the children's family background.

- To ascertain the family's view about what is needed for themselves and their children.

- To produce a Name List of children working in the streets.

- To promote information and concern about this group of vulnerable children. 


\section{SURVEY METHODOLOGY}

1. The 10 most populous districts of Kabul were selected for the Needs Assessment of Children Working in the Streets in Kabul. (Refer to Appendix A for a list of Districts.) Districts 7 and 8 were not surveyed as these are unpopulated districts due to their proximity to the front-line and insecurity in these areas. District 3 is also unpopulated, due to almost complete destruction of this neighbourhood during the fighting in 1993 and 1994. District 14 was omitted, as it is $15 \mathrm{~km}$. from the centre of Kabul, and also near the front-line.

2. The survey questionnaire was designed, in consultation with the ACBAR Survey Unit. (Refer to $\Lambda$ ppendix $B$ for a copy of the questionnaire.)

3. Intervicws were held, and 20 surveyors selected according to the following criteria:

- Keen interest.and sympathy towards street children.

- Energetic, in good health, and a commitment to work hard.

- Aged 20 - 35

- Presently unemployed

- B.A. or Baccalaureate

- Readiness to work in all districts of Kabul City, and in surrounding areas.

- Speaks Dari and Pushto, with knowledge of English preferable.

- Not related to any employee of any of the organisations involved in the project.

- Previous survey experience preferable.

- Priority given to returned refugees or displaced families.

4. The 20 surveyors were divided into 10 teams (one man and one woman per team), and the surveyors were given a one-day training in the correct identification of children working in the streets, and the use of the questionnaire. The surveyors practiced using the questionnaire with children attending the Aschiana Centres.

5. The surveyors piloted 100 questionnaire, interviewing 10 children and their families in each of the 10 districts.

6. After piloting the questionnaire, surveyors were given an opportunity to discuss any difficulties they had in using the questionnaire. The questionnaire was subsequently revised and finalised. Surveyors were given additional training in the use of the questionnaire.

7. The 10 teams of surveyors worked in 10 districts of Kabul for 28 days to survey 2,000 children who were working in the streets, and their families. The children were initially identified while working in the street, and selected for interview after an initial period of introduction and confirmation that the child had been working in the street for a minimum of one month. Attempts were made to interview the child in private, although this was often not possible. Arrangements were then made to go to the child's house to interview his/her family. This was possible in all but 8 cases, where the family lived too far away, or too near the front-line to visit. 
8. Each day, the supervisors monitored all survey teams, to ensure that children were being correctly selected, that interviews were being conducted properly, and that questionnaires were completed accurately.

9. After completing the survey of 2,000 children and their families, the surveyors worked an additional 10 days to identify and list all the children working in the streets in the 10 selected districts of Kabul. A total of 28,000 children were identilicd. This name list includes the name, age, and gender of each child, and will be made available for those agencies interested in establishing programmes for children working in the strects of Kabul.

10. Completed questionnaires were delivered to the ACBAR Survey Unit in Peshawar, and data entry and analysis was undertaken from May 15th to Junc 20 th, 1995.

11. The data analyst and report writer worked together in Kabul to further analyse the data. prepare tables, and write the report. 


\section{RESULTS of the NEEDS ASSESSMENT SURVEY}

\section{PREVALENCE OF CHILDREN WORKING IN THE STREETS IN KABUL}

In the 10 districts surveyed, 28,000 children were identified who spend their days working in the streets in Kabul. ( $\Lambda$ complete namelist, including the ages, sex, and locations of these children will be available in July, 1996.)

This estimate of the number of children working in 10 districts in Kabul is not complete, as this survey only included childen observable on the streets. Surveyors did not seck out children working in closed shops, garages or factories off the streets. Thus, the actual number of child labourers in Kabul is likely to exceed 30,000 .

\section{BREAKDOWN OF 2,000 CHILDREN SURVEYED BY SEX}

Out of the 2,000 children surveyed, $1648(82.4 \%)$ were boys, and $352(17.6 \%)$ were girls.

\section{Breakdown of Crildren by Sex}

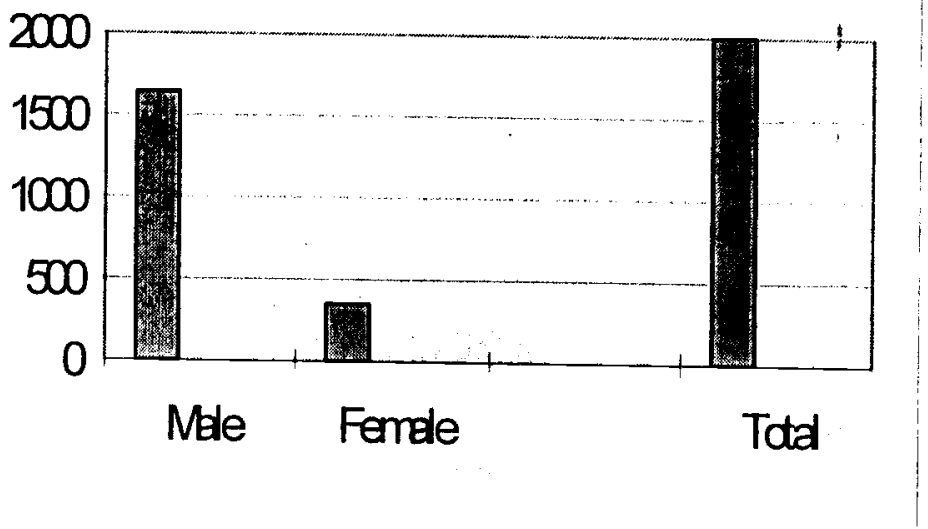

This ratio of boys to girls is approximately the same as that found in the Aschiana Centres for children working in the streets, where approximately $80 \%$ are boys, and $20 \%$ girls. 


\section{LOCATION OF THE 2,000 CHILDREN SURVEYED}

The following table summarizes the locations of the children surveyed, district by district.

Table 1: Breakdown of 2,000 children surveyed (by district)

\begin{tabular}{lrcc} 
& \multicolumn{3}{c}{ No. of children } \\
\cline { 2 - 4 } District & Male & Female & Total \\
\hline 1 & 163 & 37 & 200 \\
2 & 298 & 39 & 337 \\
4 & 140 & 60 & 200 \\
5 & 142 & 58 & 200 \\
6 & 170 & 30 & 200 \\
9 & 182 & 18 & 200 \\
10 & 156 & 44 & 200 \\
11 & 184 & 16 & 200 \\
12 & 51 & 12 & 63 \\
15 & 162 & 38 & 200 \\
\hline Total & 1648 & 352 & 2000
\end{tabular}

The low number of children identified in District 12 (PoleCharkhi) is due largely to the fact that this is an unpopulated, military zone. The children working in this area are primarily cart-pullers, transporting illegal goods.

$57 \%$ of the children work in one location only, while $43 \%$ change locations in order to earn more money or collcct suflicicnt items for the family's use.

$68 \%$ of the children surveyed work alone, and $32 \%$ work with other relatives, friends, or with a merchant. 


\section{AGES OF THE CHILDREN SURVEYED}

Table 2: Ages of children surveyed

\begin{tabular}{llllll} 
District & $<5$ & $5-7$ & $8-10$ & $11-14$ & $>14$ \\
\hline 1 & 0 & 16 & 86 & 96 & 2 \\
2 & 0 & 5 & 118 & 214 & 0 \\
4 & 1 & 6 & 62 & 124 & 7 \\
5 & 2 & 27 & 81 & 87 & 3 \\
6 & 0 & 11 & 74 & 112 & 3 \\
9 & 0 & 17 & 52 & 125 & 6 \\
10 & 0 & 14 & 69 & 113 & 4 \\
11 & 0 & 10 & 57 & 109 & 24 \\
12 & 0 & 4 & 17 & 39 & 3 \\
15 & 2 & 19 & 65 & 107 & 7 \\
\hline Total & 5 & 129 & 681 & 1126 & 59 \\
\hline
\end{tabular}

Table 2A: Age of boys

\begin{tabular}{lccccc} 
District & $<5$ & $5-7$ & $8-10$ & $11-14$ & $>14$ \\
\hline 1 & 0 & 9 & 66 & 86 & 2 \\
2 & 0 & 4 & 99 & 195 & 0 \\
4 & 0 & 5 & 46 & 82 & 7 \\
5 & 1 & 22 & 50 & 67 & 2 \\
6 & 0 & 10 & 56 & 101 & 3 \\
9 & 0 & 13 & 46 & 117 & 6 \\
10 & 0 & 10 & 46 & 96 & 4 \\
11 & 0 & 8 & 46 & 106 & 24 \\
12 & 0 & 2 & 11 & 35 & 3 \\
15 & 0 & 13 & 51 & 91 & 7 \\
\hline \multirow{2}{*}{ Total: } & 1 & $9 d$ & 517 & 976 & 58
\end{tabular}

\section{Table 2B: Age of girls}

\begin{tabular}{lccccc} 
District & $<5$ & $5-7$ & $8-10$ & $11-14$ & $>14$ \\
\hline 1 & 0 & 7 & 20 & 10 & 0 \\
2 & 0 & 1 & 19 & 19 & 0 \\
4 & 1 & 1 & 16 & 42 & 0 \\
5 & 1 & 5 & 31 & 20 & 1 \\
6 & 0 & 1 & 18 & 11 & 0 \\
9 & 0 & 4 & 6 & 8 & 0 \\
.10 & 0 & 4 & 23 & 17 & 0 \\
11 & 0 & 2 & 11 & 3 & 0 \\
12 & 0 & 2 & 6 & 4 & 0 \\
15 & 2 & 6 & 14 & 16 & 0 \\
\hline 10 & 4 & 33 & 164 & 150 & 1 \\
\hline
\end{tabular}

While the majority of children fall between the ages of 11 and 14, it is disconcerting to discover that there are so many children under the age of 10 working on the streets. The 5 children under the age of 5 were all collecting paper and firewood. 


\section{ETHNICITY OF CHILDREN SURVEYED}

Pashtun Tajik Hazara Uther

$\begin{array}{llllll}\% \text { of Children: } & 13 & 76 & 11 & 0 & 1\end{array}$

\section{EDUCATION OF CHILDREN SURVEYED}

Of the 2,000 children surveyed, $59.8 \%$ had attended school at some time, and $40.2 \%$ had not. The number of years the children had attended shool is summarised below:

Table 3: No. of years attended school

\begin{tabular}{ccccccc}
\cline { 2 - 6 } & 1 & 2 & 3 & 4 & 5 & $>5$ \\
\hline No. of children & 275 & 306 & 168 & 168 & 118 & 161 \\
\hline
\end{tabular}

Out of these 1,196 children who have attended school, 881 (44\% of children surveyed) are

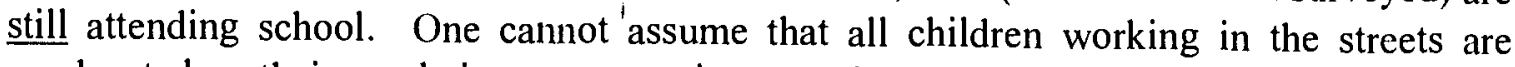
uneducated -- their work is an economic necessity in order to supplement the family income, and their work schedulc is before/after the 2 or 3 hours they attend sclool.

Out of the 1,196 children who have attended school, 315 children had stopped going to school. The reasons they gave are as follows (some children gave more than one answer):

Table 4: Reasons why the child stopped attending school

\begin{tabular}{lccccccccc}
\cline { 3 - 7 } & a & b & c & d & e & f & g & h & $i$ \\
\hline No. children & 10 & 6 & 87 & 191 & 14 & 63 & 1 & 10 & 29 \\
\hline
\end{tabular}

List of reasons:

a. Death of parent

b. Disability of parent

c. Displacement

d. Economic problems

e. Family forced child to leave school to work

f. Fighting

g. Health problem

h. No guardian to support the family

i. School destroyed 


\section{LENGTH OF TIME THE CHILDREN HAVE WORKED IN THE STREET}

$64 \%$ of the children interviewed have been working in the streets for one year or less. $34 \%$ have been working for more than 22 months. A complete breakdown is summarized in Table 5 .

Table 5. Length of time working on the street

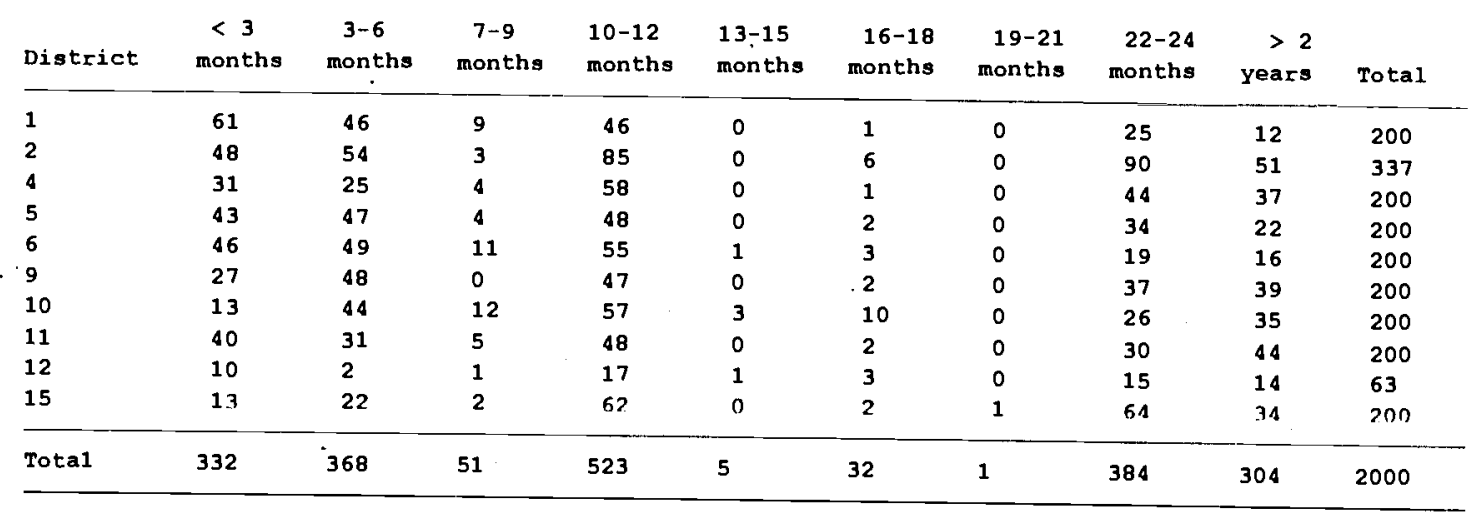

Table 5A Length of time working on the street (Boys)

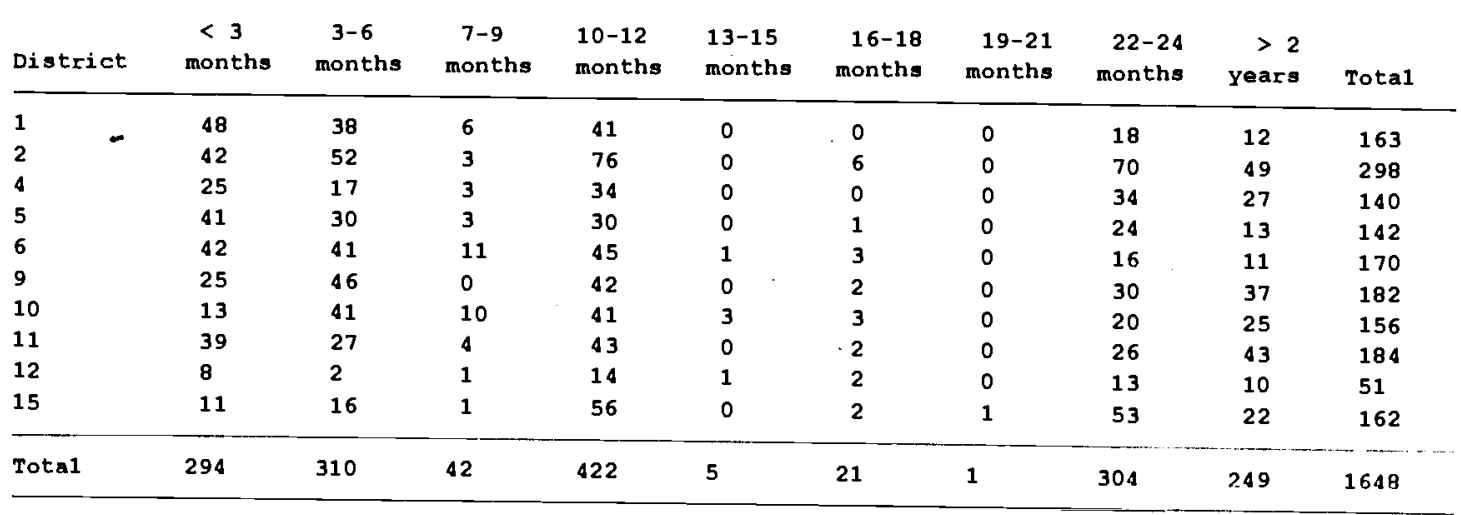

Table 5B Length of time working on the street (Girls)

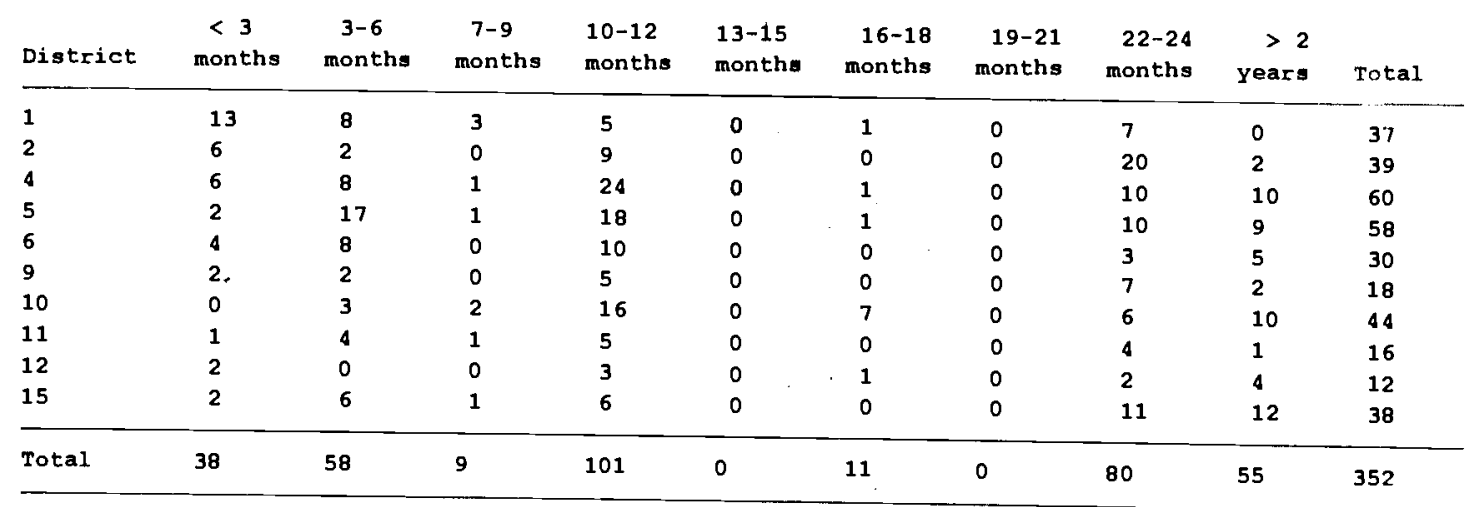




\section{WORKING HOURS OF THE CHILDREN}

$86 \%$ of the children interviewed said that they worked every day (i.e. 7 days per week), and a further $9 \%$ said they worked 6 days per week. Most of the children work long hours. with 929 children (46\%) saying they work 10 or more hours per day.

Table 6: Working hours of the children

\begin{tabular}{lcccccccccccccc} 
& \multicolumn{11}{c}{ No. of hours per day } \\
\cline { 2 - 14 } & 1 & 2 & 3 & 4 & 5 & 6 & 7 & 8 & 9 & 10 & 11 & 12 & $>12$ \\
\hline No. of children & 4 & 13 & 36 & 77 & 116 & 157 & 172 & 218 & 278 & 376 & 291 & 133 & 129 \\
\hline
\end{tabular}

Table 6A: Working hours of the children (Boys)

\begin{tabular}{lllllllllllllll} 
& \multicolumn{11}{c}{ No. of hours per day } \\
\cline { 2 - 12 } & 1 & 2 & 3 & 4 & 5 & 6 & 7 & 8 & 9 & 10 & 11 & 12 & $>12$ \\
\hline No. of children & 2 & 5 & 24 & 61 & 95 & 144 & 144 & 179 & 216 & 295 & 244 & 119 & 120 \\
\hline
\end{tabular}

Table 6B: Working hours of the children (Girls)

\begin{tabular}{llllllllllllll} 
& \multicolumn{11}{c}{ No. of hours per day } \\
\cline { 2 - 13 } & 1 & 2 & 3 & 4 & 5 & 6 & 7 & 8 & 9 & 10 & 11 & 12 & $>12$ \\
\hline No. of children & 2 & 8 & 12 & 16 & 21 & 13 & 28 & 39 & 62 & 81 & 47 & 14 & 9 \\
\hline
\end{tabular}




\section{WHAT WORK DO THE CHILDREN DO?}

The most common types of work done by the children surveyed are collecting firewood. selling small items (matches, toilet paper, key tags, soap, etc.), selling food or drink, and collecting paper. A summary of the types of work done by the children follows:

\section{Table 7: Type of work}

\begin{tabular}{|c|c|c|c|c|c|c|c|c|c|}
\hline District & $\begin{array}{l}\text { Collecting } \\
\text { firewood }\end{array}$ & $\begin{array}{l}\text { Collecting } \\
\text { paper }\end{array}$ & $\begin{array}{r}\text { Carrying } \\
\text { garbage }\end{array}$ & $\begin{array}{l}\text { Polishing } \\
\text { shoes }\end{array}$ & $\begin{array}{l}\text { Cleaning } \\
\text { cars }\end{array}$ & $\begin{array}{c}\text { Selling } \\
\text { small } \\
\text { items }\end{array}$ & $\begin{array}{c}\text { Begging } \\
\text { for } \\
\text { money }\end{array}$ & $\begin{array}{l}\text { Selling } \\
\text { i l legal } \\
\text { i tens }\end{array}$ & $\begin{array}{l}\text { Other } \\
\text { work }\end{array}$ \\
\hline 1 & 41 & 26 & 0 & 7 & 0 & 54 & 3 & 0 & 107 \\
\hline 2 & 14 & 25 & 0 & 11 & 8 & 50 & 4 & 0 & 239 \\
\hline 4 & 99 & 25 & 1 & 6 & 3 & 34 & 9 & 0 & 52 \\
\hline 5 & 98 & 19 & 1 & 0 & 0 & 25 & 2 & 0 & 72 \\
\hline 6 & 56 & 11 & 0 & 4 & 2 & 54 & 6 & 0 & 69 \\
\hline 9 & 60 & 54 & 2 & 4 & 16 & 61 & 1 & 1 & 56 \\
\hline 10 & 55 & 49 & 0 & 12 & 8 & 36 & 10 & 0 & 74 \\
\hline 11 & 29 & 17 & 0 & 2 & 7 & 36 & 4 & 0 & 124 \\
\hline 12 & 13 & 10 & 1 & 5 & 2 & 7 & 2 & 0 & 26 \\
\hline 15 & 42 & 23 & 0 & 11 & 6 & $3 n$ & 1 & $n$ & a) \\
\hline No. of child: & 507 & 259 & 5 & 62 & $52^{\circ}$ & 395 & 45 & 1 & 902 \\
\hline
\end{tabular}

Table 7A: Type of work (Boys)

\begin{tabular}{|c|c|c|c|c|c|c|c|c|c|}
\hline District & $\begin{array}{l}\text { Collecting } \\
\text { fi rewood }\end{array}$ & $\begin{array}{l}\text { Collecting } \\
\text { papar }\end{array}$ & $\begin{array}{r}\text { Carrying } \\
\text { garbage }\end{array}$ & $\begin{array}{c}\text { Polishing } \\
\text { shoes }\end{array}$ & $\begin{array}{l}\text { Cleaning } \\
\text { cars }\end{array}$ & $\begin{array}{l}\text { selling } \\
\text { small } \\
\text { it toms }\end{array}$ & $\begin{array}{l}\text { Begging } \\
\text { for } \\
\text { money }\end{array}$ & $\begin{array}{l}\text { Sol } 11 \text { ng } \\
11 \text { lognd } \\
1 \text { tems }\end{array}$ & $\begin{array}{l}\text { othar } \\
\text { work }\end{array}$ \\
\hline$\ldots$ & 25 & 17 & 0 & 7 & 0 & 50 & 2 & 0 & 90 \\
\hline 2 & 4 & 12 & 0 & 11 & $\mathbf{8}$ & 47 & 0 & 0 & 221 \\
\hline 4 & 51 & 14 & 1 & 6 & 3 & 32 & 6 & 0 & 41 \\
\hline 5 & 52 & 11 & 0 & 0 & 0 & 25 & 1 & 0 & 66 \\
\hline 6 & 33 & 9 & 0 & 4 & 2 & 53 & 3 & 0 & 68 \\
\hline 9 & 42 & 39 & 2 & 4 & 16 & 61 & 0 & 1 & 56 \\
\hline 10 & 26 & $1 B$ & 0 & 12 & 8 & 34 & 6 & 0 & 71 \\
\hline 11 & 17 & 12 & 0 & 2 & 7 & 35 & 2 & 0 & 123 \\
\hline 12 & B & 5 & 1 & 5 & 2 & 7 & 1 & 0 & 25 \\
\hline 15 & 24 & 7 & 0 & 11 & 6 & 3 & 1 & 0 & 80 \\
\hline No. of boys & 282 & 144 & 4 & 62 & 52 & 381 & 22 & 1 & 841 \\
\hline
\end{tabular}

Table 7B: Type of work (Giris)

\begin{tabular}{|c|c|c|c|c|c|c|c|c|c|}
\hline District & $\begin{array}{l}\text { Collecting } \\
\text { fl rewood }\end{array}$ & $\begin{array}{l}\text { Collecting } \\
\text { paper }\end{array}$ & $\begin{array}{r}\text { Carrying } \\
\text { garbage }\end{array}$ & $\begin{array}{l}\text { I } \\
\text { Polishing } \\
\text { shoes }\end{array}$ & $\begin{array}{l}\text { Cleaning } \\
\text { cars }\end{array}$ & $\begin{array}{l}\text { Selling } \\
\text { small } \\
1 \text { tems }\end{array}$ & $\begin{array}{l}\text { Begging } \\
\text { for } \\
\text { money }\end{array}$ & $\begin{array}{l}\text { Selling } \\
\text { i l legal } \\
\text { i tems }\end{array}$ & $\begin{array}{r}\text { Other } \\
\text { work }\end{array}$ \\
\hline 1 & 16 & 9 & 0 & 0 & 0 & 4 & 1 & 0 & 17 \\
\hline 2 & 10 & 13 & 0 & 0 & 0 & 3 & 4 & 0 & 18 \\
\hline 4 & 48 & 11 & 0 & 0 & 0 & 2 & 3 & o & 11 \\
\hline 5 & 46 & 8 & 1 & 0 & 0 & 0 & 1 & o & 6 \\
\hline 6 & 23 & 2 & 0 & 0 & 0 & 1 & 3 & 0 & 1 \\
\hline 9 & 18 & 15 & 0 & 0 & 0 & 0 & 1 & 0 & 0 \\
\hline 10 & 29 & 31 & 0 & 0 & 0 & 2 & 4 & 0 & 3 \\
\hline 11 & 12 & 5 & 0 & 0 & 0 & 1 & 2 & 0 & 1 \\
\hline 12 & 5 & 5 & 0 & 0 & 0 & 0 & 1 & 0 & 1 \\
\hline 15 & 18 & 16 & 0 & 0 & 0 & 1 & 3 & 0 & 3 \\
\hline No. of girls: & 225 & 115 & 1 & 0 & o & 14 & 23 & 0 & 61 \\
\hline
\end{tabular}


The most frequent types of work listed under 'other' include:

\begin{tabular}{lr} 
Type of Work & No. of Children \\
\cline { 2 - 2 } Selling food and drink & 479 \\
Espandi (incense) & 151 \\
Collecting fuel (diesel) & 71 \\
Cart Driver & 69 \\
Selling Cigarettes & 51 \\
Mechanical Work & 42 \\
Porter & 27 \\
Gun Target game & 6 \\
Collecting scrap metal & 3 \\
Bakery worker & 3
\end{tabular}

\section{HOW MUCH DO THE CHILDREN EARN?}

$71 \%$ of the children interviewed earned money for the work they did. The other $29 \%$ took the produce of their labours home -- wood, paper, and dung to use as fucl for cooking and heating. The jobs which earn the highest income (more than Afs 4,000 per day) are selling food and drinks, selling cigarettes, and cart driving. The lowest amount of money is earned by espandi children, selling small items, and collecting fuel.

All the children except 10 said that they give the money they earn to their fanuily or relatives. Ten children said that they keep the money for themselves.

Table 8 (next page) summarizes the income of the children participating in this survey.

\section{PROBLEMS OF CHILDREN WORKING IN THE STREETS}

Out of the 2,000 children interviewed in this Needs Assessment Survey, 91\% said they did not like working in the street. They complained that the work was hard, that they were often cold or wet, that they did not have enough to eat, that they were disturbed by police or soldiers, that they were frightened by rockets, and that they often had to travel long distances to find work.

21 children said they had been threatened by 'armed men' for being in prohibited areas, blocking the road, begging, or making the road muddy by washing cars. (It was difficult for the children to differentiate between police, government soldiers, or mujahedeen.) $\Lambda$ few children said they had been made to pay money at checkposts. One child said he had been arrested and held for several hours for collecting wood in a military zone.

It has often been assumed that children are used to carry illegal items (including drugs) throughout Afghanistan. However, during the course of this survey, no children admitted to being involved in drug trafficking. One child said that he had taken drugs, and 21 children said they smoked cigarettes. 


\section{Table 8: Income Earned by Children per Day}

$\Lambda$ mount of money earned by children per day ( $A$ is $)$

\begin{tabular}{rcccccr} 
No & $<1000)$ & $1000-$ & $2000-$ & $3000-$ & $400(0)$ & $>5000$ \\
Income & & 2000 & 3000 & 4000 & 5000 & \\
\hline No. of Children: 585 & 76 & 409 & 463 & 278 & 95 & 94
\end{tabular}

Daily Income of Children

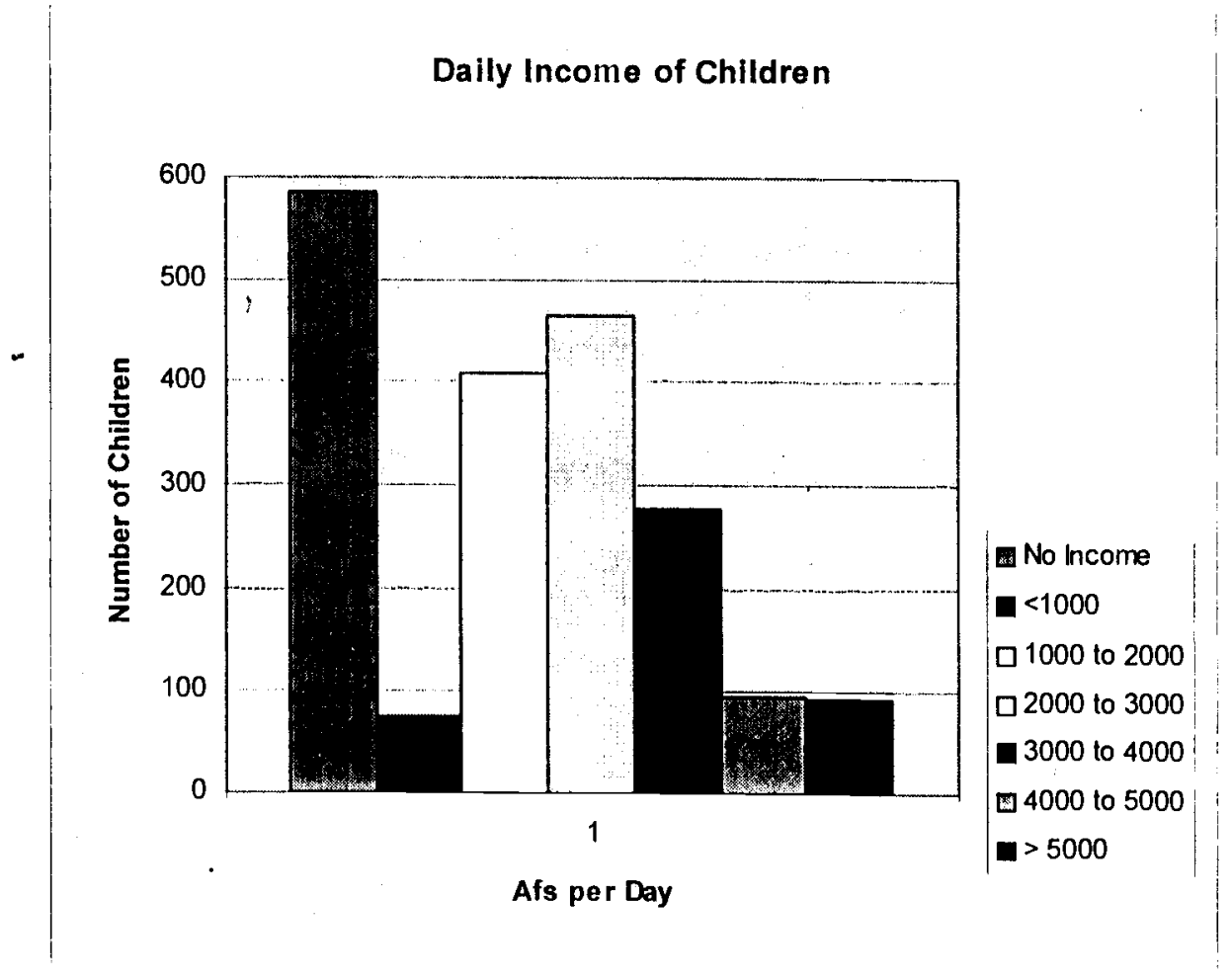




\section{HEALTH PROBLEMS OF THE CHILDREN SURVEYED}

76 children $(3.8 \%)$ were assessed as being malnourished by the surveyors. This figure must be seen as only a rough estimate, as surveyors were given only basic training on signs and symptoms of malnourished children. In subsequent visits to the families, the families reported that 145 children had died from malnutrition.

18 children were identified as being disabled: 9 were lame; 7 had some form of paralysis. and 2 were deaf.

$13 \%$ of the children surveyed were assessed as needing medical attention by the surveyors. The five most frequently identified medical problems were:

\begin{tabular}{lr} 
Medical Problem & No. of Children \\
\cline { 2 - 2 } Leichmaniosis & 110 \\
Other skin diseases & 87 \\
Eye infections & 15 \\
Psychological problems & 10 \\
Ear problems & 8
\end{tabular}

\section{WHERE DO THE CHILDREN LIVE?}

It is clear from this survey that children working in the streets in Kabul are not street children', as they do not live in the streets. All of the 2,000 children surveyed had a place to go to at night, most of them with their own families. This is a credit to the Afghan religious and cultural traditions which ensure that relatives look after each other, and refuge is offered to children without a home.

\section{Table 9: Where Do the Children Sleen?}

\begin{tabular}{|c|c|c|c|c|}
\hline & $\begin{array}{l}\text { His/her Own } \\
\text { Home }\end{array}$ & $\begin{array}{l}\text { Relative's } \\
\text { Home }\end{array}$ & $\begin{array}{c}\text { Friend's } \\
\text { Home }\end{array}$ & Other \\
\hline o. of Children: & 1,969 & 26 . & 2 & 3 \\
\hline
\end{tabular}

The three children. listed under 'other' slept at their father's place of work (a butchery, a bakery, and an auto repair shop). 


\section{CHILDREN'S FAMILY BACKGROUND}

The surveyors were able to visit the families of 1,992 of the children. Eight families were unable to be visited, as they lived too far away and/or near the front line.

In $75 \%$ of these families, the father was alive, and living with the family.

In $23 \%$ of the families, the father had died.

In $2 \%$, the father was not living with the family (missing, living with another family.)

In $95 \%$ of these families, the mother was alive and living with the family.

In $4 \%$ of the lamilies, the mother had clied.

In $1 \%$, the mother was missing.

The exact figures are detailed in Table 10:

Table 10: Information About Parents

Father

\begin{tabular}{ll}
\multicolumn{2}{c}{ Father } \\
\hline $\begin{array}{l}\text { Living with } \\
\text { family }\end{array}$ & Dead Missing \\
\hline
\end{tabular}

No. of Families: $\quad 1,497$

452
Mother

Living with Dead Missing family

1,892

83

17

By correlating the information about the parents, the following status of the children could be obłained:

No of children living with both parents:

No. of children living with a single parent:

No. of children orphaned (both parents dead):

No. of children living without parents (parents missing)

No. of Children

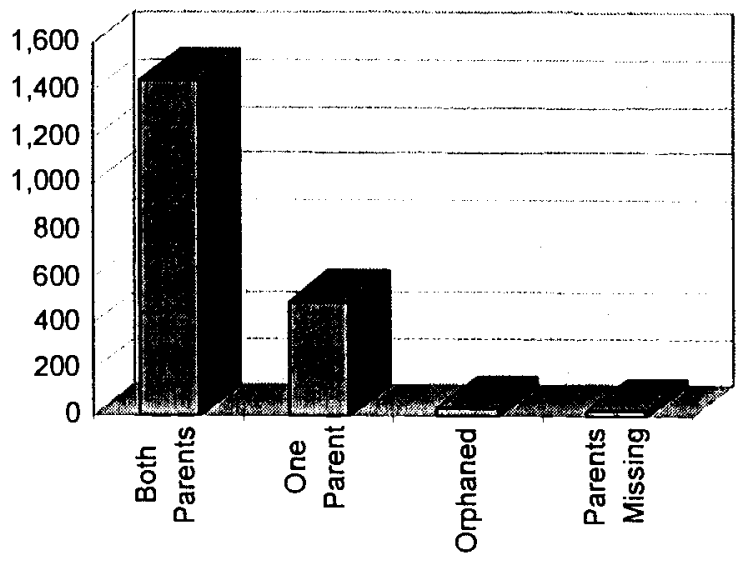

$\square$ No. of Children 


\section{SIZE OF FAMILIES}

The majority of the families interviewed had 4 to 8 children, as detailed in Table 11:

Table 11. Size of family

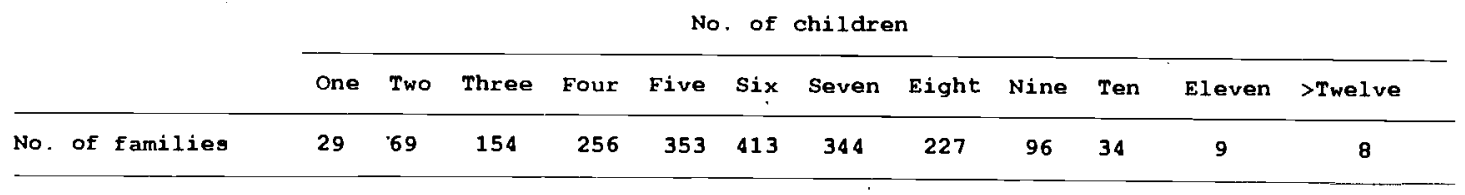

In $50 \%$ of the families surveyed, at least one child had died. The causes of these childhood deaths were:

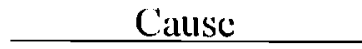

Childhood illness

Rockets, Landmine

Malnutrition

Accidental death
No. of Familics

145

15

In order to supplement the family income, many families have more than one child working on the streets:

Table 12: No. of children working in the streets per family

\begin{tabular}{|c|c|c|c|c|c|}
\hline \multirow[b]{2}{*}{ District } & \multicolumn{5}{|c|}{ No. of children working in the street } \\
\hline & One & Two & Three & Four & $>$ Five \\
\hline $\begin{array}{l}1 \\
2 \\
4 \\
5 \\
6 \\
9 \\
10 \\
11 \\
12 \\
15\end{array}$ & $\begin{array}{l}93 \\
138 \\
81 \\
52 \\
110 \\
69 \\
90 \\
87 \\
33 \\
80\end{array}$ & $\begin{array}{l}75 \\
143 \\
84 \\
91 \\
73 \\
75 \\
79 \\
77 \\
19 \\
89\end{array}$ & $\begin{array}{l}26 \\
47 \\
30 \\
44 \\
17 \\
43 \\
30 \\
33 \\
6 \\
27\end{array}$ & $\begin{array}{l}5 \\
7 \\
5 \\
11 \\
0 \\
13 \\
1 \\
2 \\
0 \\
2\end{array}$ & $\begin{array}{l}1 \\
2 \\
0 \\
1 \\
0 \\
0 \\
0 \\
1 \\
0 \\
0\end{array}$ \\
\hline Total: & 833 & 805 & 303 & 46 & 5 \\
\hline
\end{tabular}




\section{LIVING CONDITIONS OF THE FAMILIES}

$73 \%$ of the families surveyed had been displaced, and $9 \%$ were returned refugees. thus, $82 \%$ of these lamilies had left their original homes at some time. Most of the lamilies interviewed had found alternative living quarters, as their own homes were no longer habitable.

Table 13: Living Quarters of Families Interviewed

\begin{tabular}{cccccc} 
& $\begin{array}{c}\text { Own } \\
\text { home }\end{array}$ & $\begin{array}{c}\text { Rented } \\
\text { home }\end{array}$ & $\begin{array}{c}\text { Relatives } \\
\text { home }\end{array}$ & $\begin{array}{c}\text { Abandoned } \\
\text { house }\end{array}$ & Other \\
\hline \& of families & 21 & 47 & 17 & 4 & 11 \\
\hline
\end{tabular}

'Other' included government buildings, mosques, inns, tents, and neiglibours' houses.

$99 \%$ of the families interviewed had a toilet and access to a drinking water sourec. The average number of people per room was 5 .

\section{EMPLOYMENT OF PARENTS}

No. of households where both father and mother are employed: 56

No. of households where father only is employed: 1181

$\begin{array}{ll}\text { No. of households where mother only is employed: } & 130\end{array}$

No of households where neither mother nor father is employed: 245

No.of households where l parent is employed, and no information $\quad 340$ about other parent:

No.of houscholds where there is no information about both parents: $\quad 40$

\section{INCOME OF THE FAMLLIES}

In $99 \%$ of the families interviewed, the total family income per month was less than $\Lambda$ is 500,000 per month.

Table 14: Monthly Incone of Families

\begin{tabular}{|c|c|c|c|c|c|c|c|c|}
\hline \multicolumn{9}{|c|}{ Average monthly income of families surveyed (Afs) } \\
\hline & $<10,000$ & $\begin{array}{l}10,000- \\
100,000\end{array}$ & $\begin{array}{l}100,000- \\
200,000\end{array}$ & $\begin{array}{l}200,000- \\
300,000\end{array}$ & $\begin{array}{l}300,000- \\
400,000\end{array}$ & $\begin{array}{l}400,000- \\
500,000\end{array}$ & $>500,000$ & $\begin{array}{c}\text { No } \\
\text { income }\end{array}$ \\
\hline No. of families & $\mathbf{0}$ & 478 & 811 & 414 & 212 & 53 & 12 & 12 \\
\hline
\end{tabular}


Monthly Income of Families

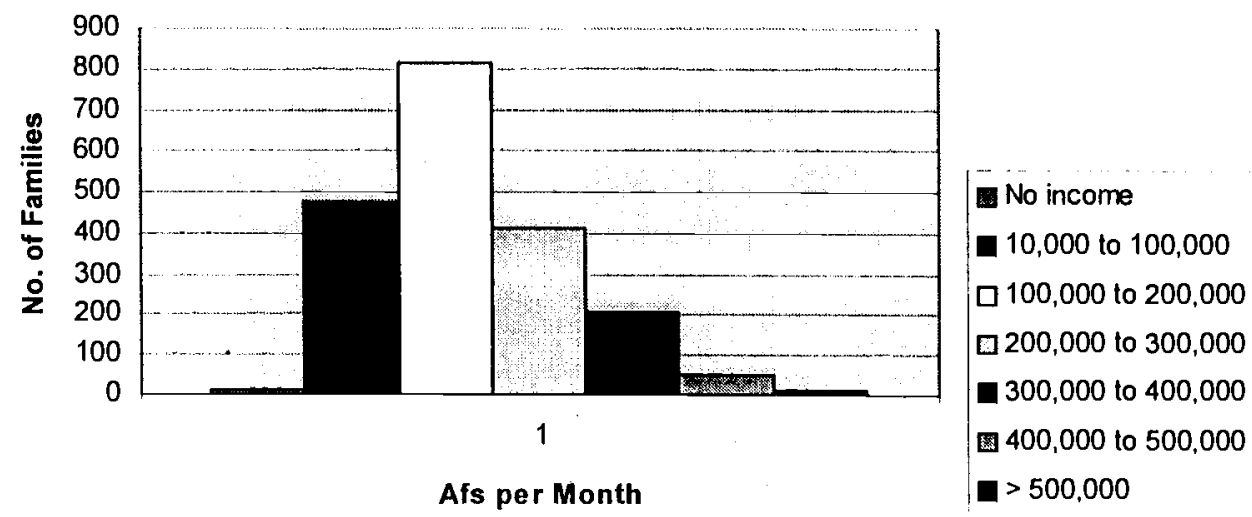

\section{FAMILIES' PERCEPTIONS OF WHY THEIR CHILDREN ARE WORKING IN THE STREET}

All families were asked their views as to why their children were working in the streets. The most common reason given was poverty: the children had to work in order to supplement the family's income, or to provide fuel. Many people expressed the view that their poor economic situation was due to the many years of fighting, and loss of their homes and possessions.

The replies are summarized in Table 15:

Table 15: Families' Perceptions of Why Their Children are Working in the Street

$\underline{\text { Reasons why children are working in the Streets }}$
$\Lambda$
B C
D $\quad$ E
E $\quad \mathrm{F} \quad \mathrm{G}$

No. of Replies: $\quad \begin{array}{llllllll}7778 & 201 & 302 & 199 & 57 & 814 & 4\end{array}$

$\begin{array}{ll}\text { List of Reasons: } & \text { A: Poverty } \\ & \text { B: Death of Parent } \\ & \text { C: Sickness/disability of parent } \\ & \text { D: Displacement/no shelter } \\ & \text { E: Unemployment of parent } \\ \text { l:: Continuous fighting/war } \\ \text { G: School Destroyed }\end{array}$




\section{FAMILIES' PERCEPTIONS OF ASSISTANCE NEEDED}

The families were asked what kind of assistance could be given so that their child would no longer have to work on the street. Their replies were as follows (many families gave several replies):

Table 16: Families' Perceptions of Assistance Needed

\begin{tabular}{lcccccccccc} 
& \multicolumn{1}{c}{} & \multicolumn{1}{c}{ Assistance needed } \\
\cline { 2 - 10 } & A & B & C & D & E & F & G & H & I \\
\hline No. of Replies: & 208 & 68 & 1568 & 422 & 258 & 136 & 10 & 9 & 512 \\
\hline
\end{tabular}

List of Assistance Needed:
A. Employment for parent/income generation schemes
B. Providing food, clothing, shelter, fuel, or other material goods
C. Establishment of vocational training programmes for children
D. Financial assistance to the family/credit/bonus schemes
E. Providing funds for school expenses
F. Em̈ployment for children
G. Treatment of the children's health problems
H. Establishment of schools for disabled
I. Peace/providing stable and secure conditions 


\section{SUMMARY AND CONCLUSIONS}

1. This survey of children working in the streets in Kabul identified 28,000 children who were working in 10 districts of Kabul. The term 'street children' should not be applied to these children, as the children do not live in the streets -- they work there. All 2,000 children surveyed had a home to go to at night, most of them with their own families.

2. Of the 2,000 children surveyed, $82 \%$ were boys, and $18 \%$ girls.

3. Overall, the largest proportion of children surveyed were in the age group $11-14$. However, amongst the girls, the largest proportion (47\%) were aged $8-10$. This is a particularly vulnerable age for girls, and is cause for concern.

4. The general assumption that children working in the streets do not attend school was not confirmed by the survey results. $60 \%$ of children surveyed had attended school at some time, and $44 \%$ were still attending on a regular basis.

5. $29 \%$ of the children surveyed work to provide their families with fuel, and do not earn money. The majority of children who earn money earn between Afs 2,000 to Afs 3,000 per day. If the children were to stop working, their families would need to find an alternative way to find this income of Afs 75,000 per month.

6. The strongly held belief that the children working in the streets of Kabul are orphaned or from single-parent families proved not to be the case. $73 \%$ of children surveyed live with both parents, and only $2.6 \%$ of the children were orphaned (both parents dead or missing).

7. A high percentage of the families surveyed were displaced: $73 \%$ had been internally displaced, and $9 \%$ were returned refugees.

8. The primary reason why so many children are working in the streets is poverty, and the poor economic situation in Kabul. The total family income per month for $99 \%$ of families interviewed was < Afs 500,000 (\$33).

9. The type of assistance most frequently requested by the families surveyed was vocational training for the children, and financial assistance for the families. 


\section{DISTRICTS FOR NEEDS ASSESSMENT SURVEY}

District \# 1 - Old City

District \# 2 - De-Afghanan and Jadi- Aasmaiee

District \# 4 - Bagh-i-Zanana, Taimanai, 2nd Parwan, Chaman-i-Babrak, and Dhekepack

District \# 5 - Khoshal-Khan, and Company

District \#6 - Pole-Sokhta, Qalai-Shada, Pole-Surkh, Dashti-Barchi, and Karti-Se

District \# 9 - Microrayan, and Babi-Mahro

District \# 10 - Shari-i-Now

Districts \# 11 \& 15 - Khair Khana

District \# 12 - Pole Charkhi 


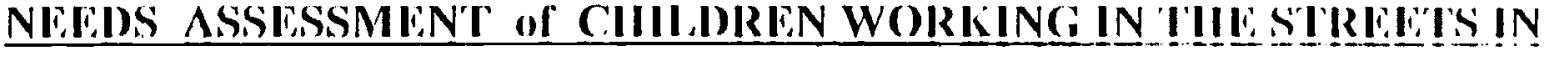 KABUL}

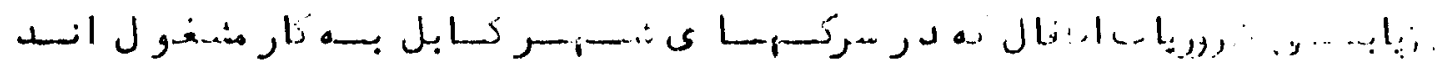

Sorjal No:

Surveyor's Nante (c 'ode):

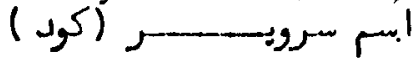

Dille:

تاريخن

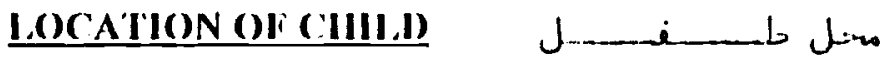

I)istrict No:

l.ocalion of Working Place:

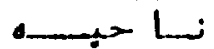

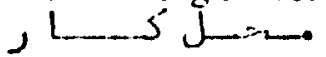

1.ocation of Slecping Place ( 1 delress):

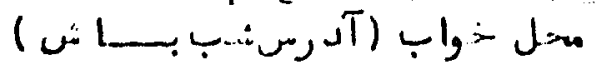

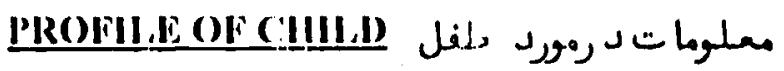

1. Nanne:

p

2. Sex:

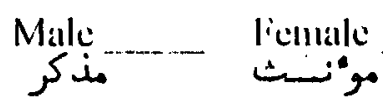
3. Age:
a. $\therefore 5$
b. $5-7$
c. $8-10$
(1. $11-14$
c. $\cdot 1+1$

4. Place of [3irtls:

$$
\text { ولايت }
$$

District:

5. Ethnicity:
a. Pashlitun
b. lajik 选
c. Ilazara
هـزاره
d. Ix)心

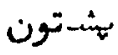

تسومبـت

(c. Other (Specily):

6. Are youl educalcel?

آيا تعليم يأنته هسيتيده

بلئي

No

ll yes, how many years dicl you attend school? y'ars.

Jher \&

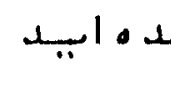

Do you still allend school'?

آيا منوز هم مكتب ميرويد

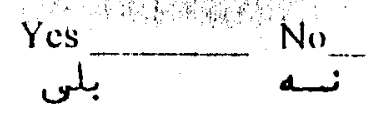

If no, why did you stop allending schlool?

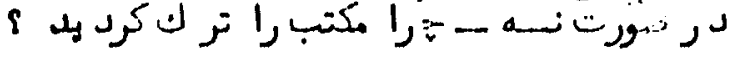

1.

2. 3. 


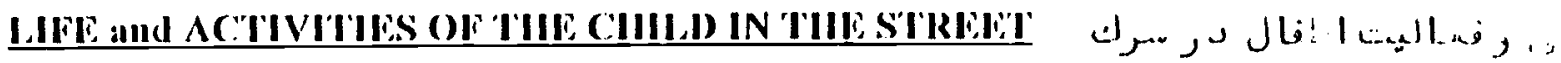

7. Ilow long have you been working in the street?

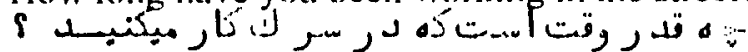
(I)alys, momilıs, of yciols)

8. Why did you first start working in the street?

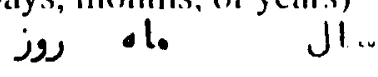

:

1 . 2.

3.

9. Where do you most oflen go lor work?

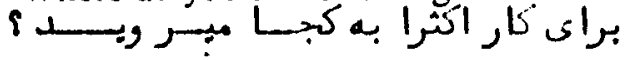

I0. Do you work in one place, or change locations"?

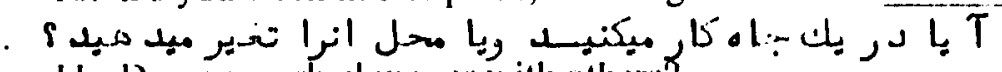

II. 1)0 you work allone, or with otlers?

آيا تنهـا كأر ميكنيد ويا با لد يكران

Il working with otlers, who are lley"?

1.

2.

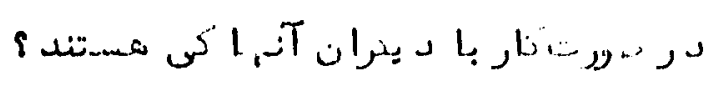

3.

12. Working time:

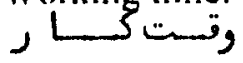

Usual starting time:

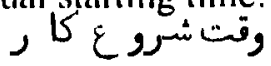

13. How many days a week do you work?

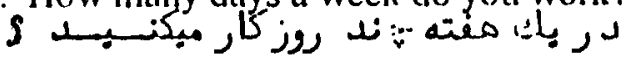

14. What kind of work are you doing?

$$
\text { \& }
$$

a. Collecting lirewood

$$
\text { - }
$$

b. collectiug paper بشمع أورى كاغن

c. Carrying garbange

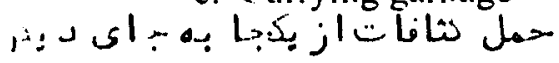

d. Polishing slocs

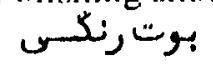

Usıal linishing line:

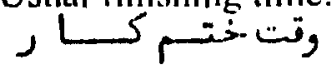

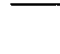


1). What do youl call during working time?

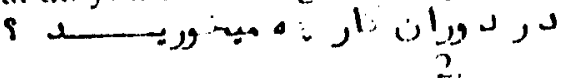

18. Where do you slece al niglil?

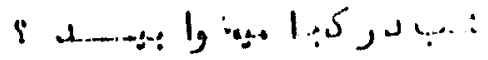

11. III his:/hu lımI1

$$
\text { د, }
$$

1. In riallive's linture

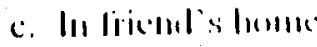

d. In the strecl

ب.

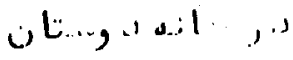

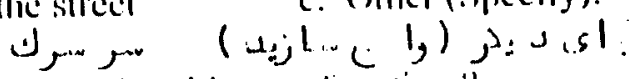

11). What do you do with your lice lime":

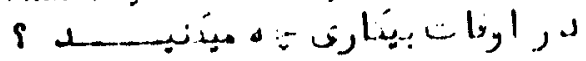

1.

211. 1) gour smolic cigarelles?

id__.

21. 10 your eve talke dingst?

Il yes, which onles? 1

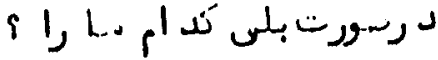

1

i.

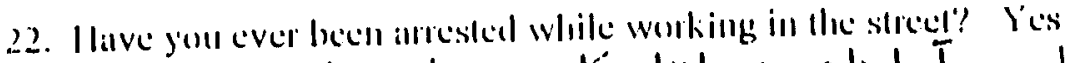

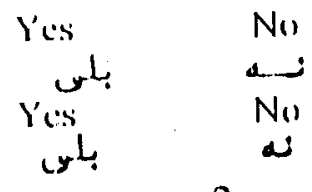

2.

3.

بله

No

If yës, by whom!?

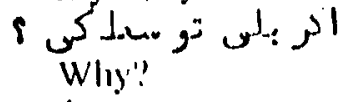

$\{1,0$

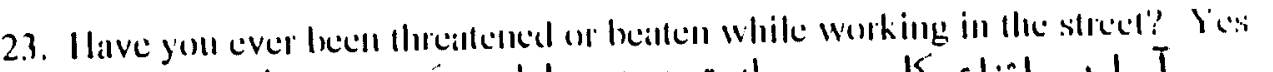

ز....

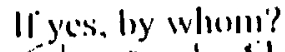

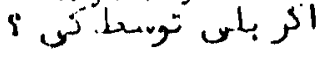

Why'?

i $1,-5$

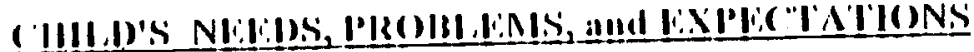

1. In youl like working in lle sincel? Yes No

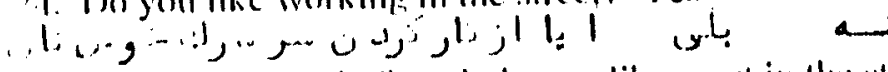

Il yes, whisl himl al work do youl like mos:t in llke stacel"

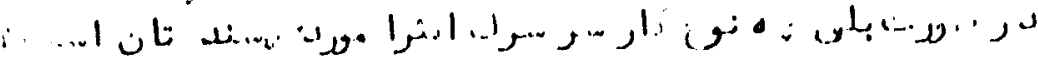

1.

2.

3.

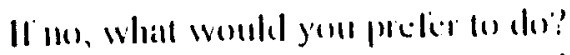

1.

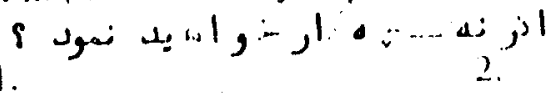


25. Do you have any problems while working in the strect? Yes

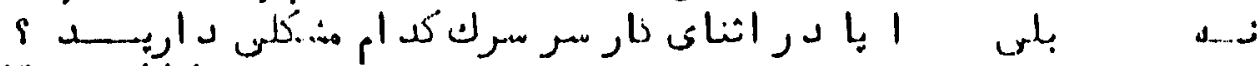
If yes, which ones:

i اs بs:

1.

2.

3.

\section{SURVISYOR'S OIBSLRVATIONS ABOUT TIL (IILI) INIERVIUIVUI):}

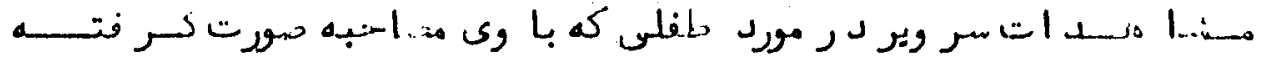

26: Does the child need uncelical allention?

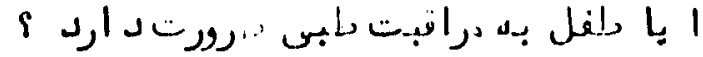

Yes No

II yes, whit alle tlic medical problemss?

م........

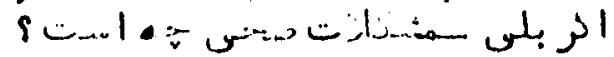

1.

2.

3.

27. Does lla cliilal look: ('lein!

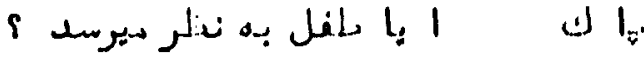

Dirty

U.

28. Does the child look malloourished?

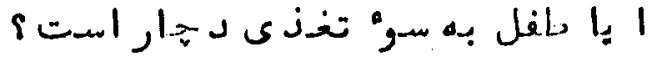

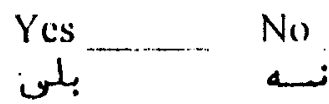

29. Is the child physically handicalpped?

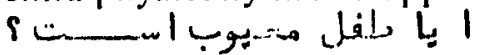

Y's _ No

If yes, give details:

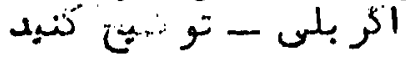

\section{(IIIIINS FAMII, BACK(IROUNI) and IIVING SITUATION}

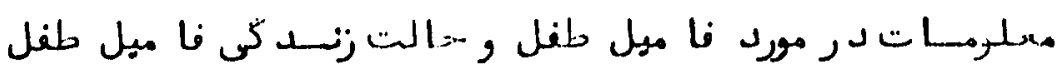

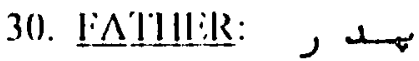

a. Alive and living will family

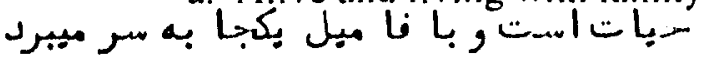

b. Alive but not living wilh limily (Where is lac?

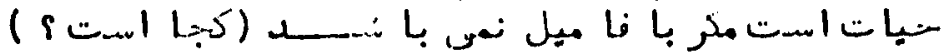

c. Deikl

$$
\text { فو }
$$

Father's $\Lambda$ ge:

$$
\text { عهم }
$$

Pathej's lrofession!

Father is prescontly:

$$
\text { مـ }
$$

liather is educilled:

كل ر تعليم يانته المدت

$$
\begin{aligned}
& \text { limployed } \\
& \text { كار د ارد } \\
& \text { Yes } \\
& \text { بل }
\end{aligned}
$$

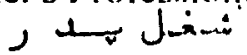

Incmployed

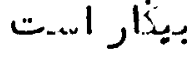

No

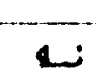




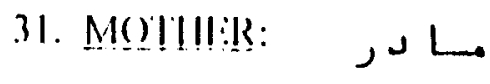

a. Alive and living with lannily

-

b. Alive but mol livinge will lamily (Where is slece?

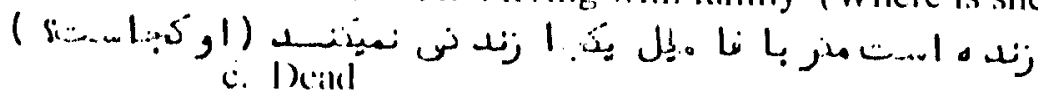

نو

Muller's $A_{g e:}$

J1. 0 as

Mriller isiprescinll: limployed

Mother is cellecilled:

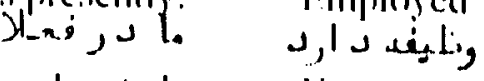

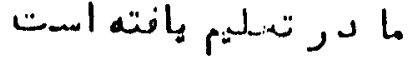

Yes

بلموا.

Muller's l'rulission:

s. l. J....

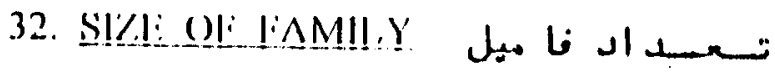

Number al childlen in llac limily:

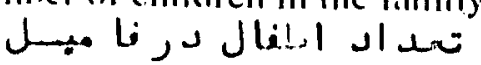

Ages of the children: lirom (loivest age)
Malc

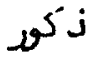

(11) llicinplonjerl

..... (5)

No

a.

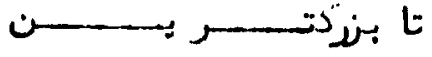

3.3. Ilave any ul yourl a hildren dicil!

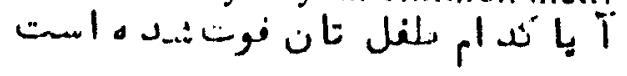

in

بلى

lintiale

$-1: 1$

(lipelless ange)

- Il yes, whill was llie callsee?

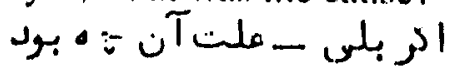

a. Wau (rockicls, limlunimess cke)

b. Malnullition

.

$$
\text { س. }
$$

e. ()llice:

$$
\text { J }
$$

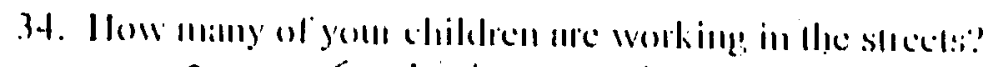

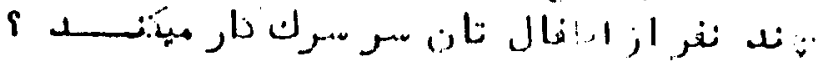
N():
2
3
.1

N.1

\& :

Six:

-

Age

pes

35. Ilave your ever been a relingere?

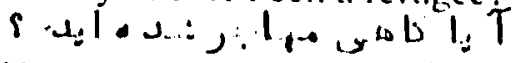

llave yoll evel heell displatecel?

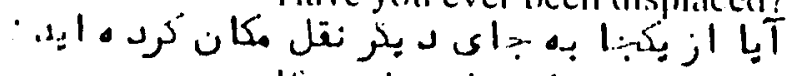

li yes, how long have youl hem living in this place."

$\begin{array}{ll}\text { lies } & \text { No } \\ \text { ines } & \text { Nos }\end{array}$

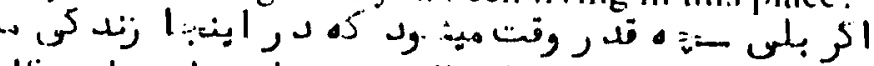

II IIo, luw long have you lived in Kalmul?

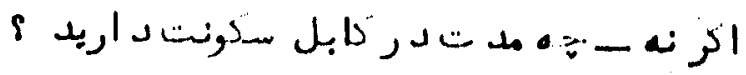




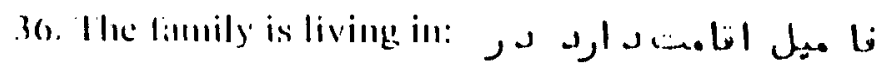
a. (1) Wh homle

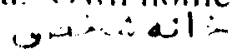
1. Rumled
¿ Relinive's linme

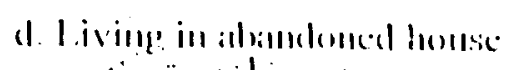

c. (Mher (sipucily)

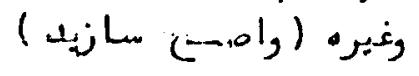

37. Ilow many romms are used lon living?

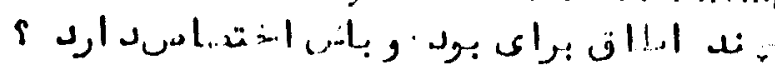

38. What is lle lolal mumber of people living in llese roums:"

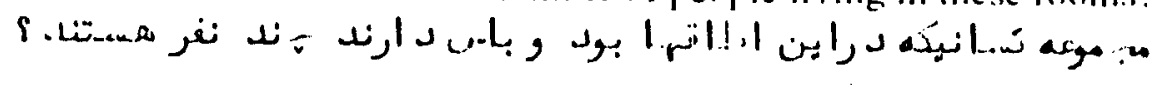

39. Whall is gutle drimhing willer somerce?

$$
\text { هنب- }
$$

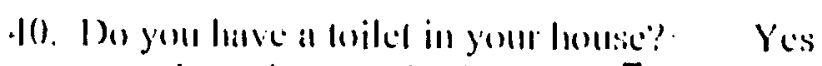

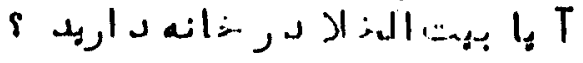
Nan

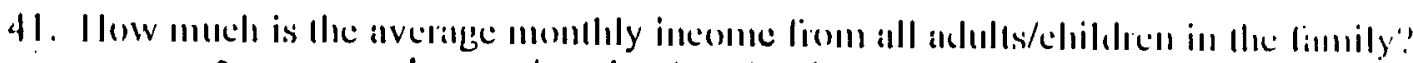

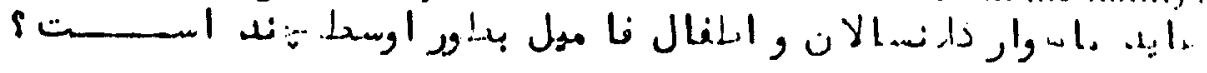

NIS

12. Who provides lle main sumec ol incumec?

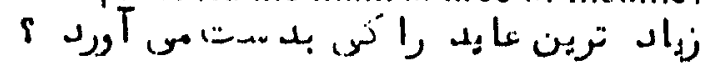

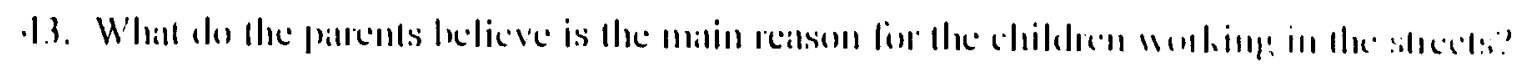

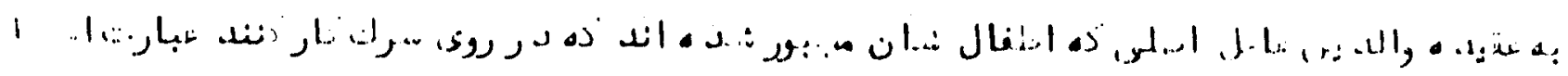

I.

2 .

3.

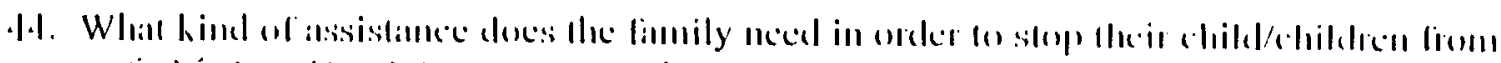

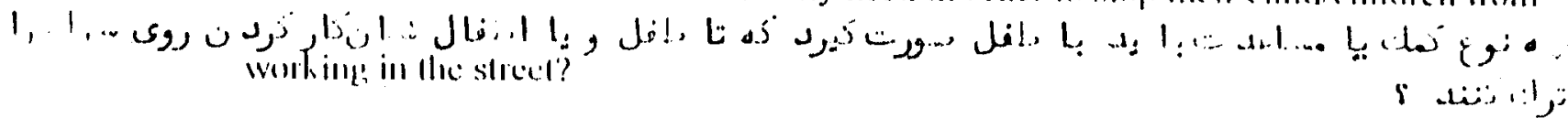
I. 